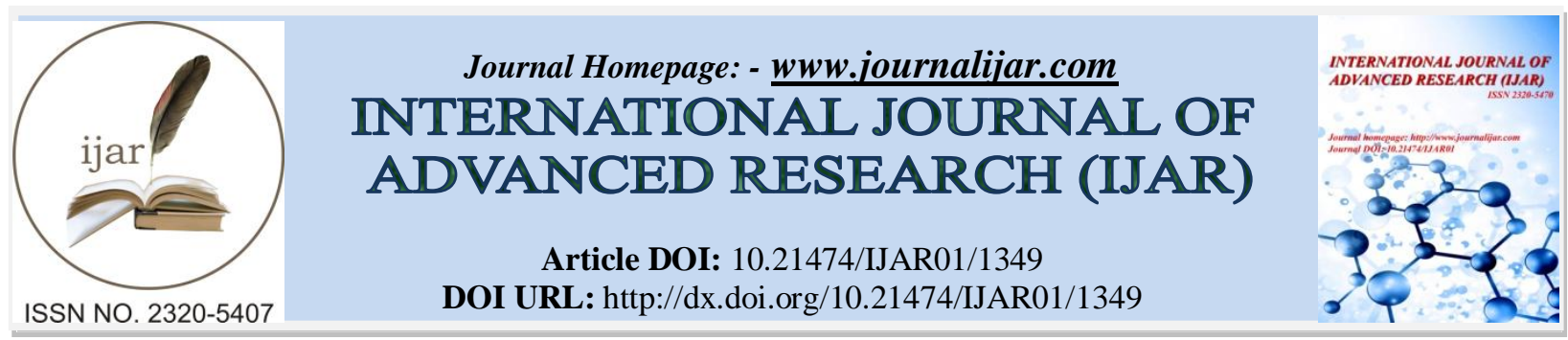

RESEARCH ARTICLE

\title{
ANALYSIS OF FLOATING COLUMN BUILDING OF COMPOSITE AND R.C.C BEAM GIRDER \& COMPARISON WITH R.C.C FRAME STRUCTURE BY USING ETABS V9.7.0.
}

Jayashri Sarode ${ }^{1}$ and Mr. Amol.S. Pote ${ }^{2}$.

1. M.E. II, Department of Civil Engineering, GHRCEM, Pune University, India.

2. Asst.Prof. Department of Civil Engineering, GHRCEM, Pune University, India.

\section{Manuscript Info}

Manuscript History

Received: 12 June 2016

Final Accepted: 22 July 2016

Published: August 2016

Key words:-

Floating column, Base Shear, Storey

drift, Displacement.

\section{Abstract}

Steel-concrete composite beams are extensively used in construction of buildings and bridge. Composite beam under applied loads are often subject to combine action of bending and vertical shear. In order to design composite beam consistently, it is necessary to develop new models for analysis of displacement, storey shear and storey drift. The floating column is a vertical element which is rest on beam, these columns are without foundation. The floating column rests on beam which is a R.C.C Beam Girder. The girder is in the form of beam and the column load acts as a point load on that transfer beam. In this seminar report the composite beam is used in Floating column structure. The composite beam is subjected to floating column; because of this we utilize the strength of composite beam. Three Models are compare in this seminar they are Normal structure, Floating column structure with R.C.C Beam Girder, Floating column structure with composite beam girder. The analyses of structure are carried out with the help of Etabs.

Copy Right, IJAR, 2016,. All rights reserved.

\section{Introduction: -}

Reinforced concrete building can adequately resist both horizontal and vertical load. Whenever there is requirement for a multistorey building to resist higher value of seismic forces, lateral load resisting system such as shear wall should be introduced in a building. In R.C.C framed structure, the no of column is present in ground floor. For parking purpose this column is an obstacle. To reduce this obstacles, the floating column concept is used. Column is float at ground level. It provides good architectural view for that building and also increase the open space for parking purpose, assembly hall etc. In this paper the research is related to R.C.C beam girder subjected to floating column and Composite beam girder subjected to floating column. This both model is comprising with the Normal R.C.C framed structure. In many research paper the floating column with R.C.C beam girder is analyzed.

In this report the composite beam is used in Floating column structure. The composite beam is subjected to floating column; because of this we utilize the strength of composite beam. Three Models are compare in this seminar they are Normal structure, Floating column structure with R.C.C Beam Girder, Floating column structure with composite beam girder. The analyses of structure are carried out with the help of Etabs.

Corresponding Author:- Jayashri Sarode.

Address:- M.E. II, Department of Civil Engineering, GHRCEM, Pune University, India. 


\section{Aim: -}

To reduce the column in ground floor, to provide more open space for Parking purpose, assembly hall etc.

\section{Objective: -}

1. The objective of present work is to study comparison of normal column structure with floating column composite beam girder structure.

2. By using this R.C.C Beam Girder more open space is available on the ground floor. These open spaces may be required for assembly hall or parking purpose.

3. Concrete is stronger in compression than in tension, and steel is susceptible to buckling in compression. By the composite action between the two, we can utilize their respective advantages to the fullest extent.

\section{Literature review: -}

The current literature survey includes composite beam analysis and earthquake response of frame structure and floating column structure. These survey emphasized on strengthening the structure in seismic region.

Arlekar, Jain and Murty (1997) publish paper in CBRI Golden Jubilee Conference on Natural Hazards in Urban Habitat in New Delhi. They have verified number of experiences of strong shaking during past earthquake. They have recognized the features are highly undesirable in seismic areas. Balsamoa, Colombo and Manfredi (2005) have comprised the original and repair structure with the reference of local and global performance. For repair they use CFRP that means Carbon Fiber Reinforced Polymer. They have represented outcomes of experimental test (pseudo dynamic test). Vassilopoulos and Beskos (2006) performed rational and efficient seismic design methodology for plane steel frames using advanced methods of analysis in the framework of Eurocodes 8 and 3. This design methodology employs an advanced finite element method of analysis that takes into account geometrical and material nonlinearities and member and frame imperfections. It can sufficiently capture the limit states of displacements, strength, stability and damage of the structure. Mounir Bouassia, Belgacem Jellali and Porbaha (2009) have analyzed the structure in the response of bearing capacity of ground surface. They have said that in a situ action where soft soil is available with thick deposition then the practical approach is to installed floating column because there is absence of rigid stratum. They have said that the length of column is not greater than the threshold value. The stresses which are cause due to foundation load within the reinforced soil mass is decrease with depth. Sukumar Behera (2012) has proposed that in seismically area the features are highly undesirable. He has analyzed the structure by using ETAB software with and without floating column. The alternate measures are also including by including stiffness balance of first storey and storey above. Pratyush Malaviya1 publish paper on International Journal of Scientific and Engineering Research, Volume 5, Issue 5, May 2014, on Comparative study of effect of floating column on the cost analysis of a structure designed on Etabs. They have compared the cost of normal column structure and floating column structure. Mr. Mahesha M, Ms. K. Lakshmi (2015) publish paper in Research Journal of Engineering and Technology International on Comparative study on 3D RC frame structure with and without floating columns for stiffness irregularities subjected to seismic loading. They study the significance of expressly perceiving the vicinity of the floating columns and significance of explicitly recognizing the presence of with and without floating column in the investigation of building furthermore alongside floating column with a few complexities were considered for $\mathrm{G}+16$ story building at different alternative location. Sabari $\mathrm{S}$, Mr. Praveen J.V(2015) publish paper in International Journal of Civil and Structural Engineering Research ISSN 2348-7607, Vol. 2, Issue 2, October 2014 - March 2015 Seismic Analysis of Multistorey Building with Floating Column. They are proposed to reduce the irregularities introduced by the floating column. They create the 2D multistorey frame with and without floating column to study the responses of structure under different earthquake excitation having different frequency content keeping the PGA and time duration factor constant. M J N Priestley (1995) publishes paper in Pacific Conference on Earthquake Engineering, PCEE 95, Melbourne, November 1995 on Displacement-based seismic assessment of existing reinforced concrete buildings. His suggestions towards the displacement based rather than forced based approach to determined available capacity. The study proposed for assessing member strength including column and beam-column joint shear strength. Shweta A. Waghe, Dr. U. P. Waghe (April 2014) Comparative Study of R.C.C and Steel Concrete Composite Structures (Case Study) They publish paper in Int. Journal of Engineering Research and Applications ISSN: 2248-9622, Vol. 4, Issue 4(Version 1), April 2014, pp.369-376. They are proposed four various multistoried commercial buildings i.e. $\mathrm{G}+12, \mathrm{G}+16$, $\mathrm{G}+20, \mathrm{G}+24$ are analyzed by using STAAD-Pro software. Where design and cost estimation is carried out using MS-Excel programming and from obtained result comparison can be made between R.C.C and composite structure. They observed under earthquake consideration because of inherent ductility characteristics, steel-concrete composite 
structure performs better than a R.C.C structure. Mahesh Suresh Kumawat, and L G Kalurkar (May 2014) Analysis and design of multistorey building using composite structure (Case Study) They publish paper in International Journal of structure and civil engineering research ISSN $2319-6009$ Vol. 3, No. 2. They are proposed a threedimensional modeling and analysis of the structure are carried out with the help of SAP 2000 software. Equivalent Static Method of Analysis and Response spectrum analysis method are used for the analysis of both Composite and RCC structures. They observed in composite structure due to high ductile nature of steel it leads to increased seismic resistance of the composite section. Steel component can be deformed in a ductile manner without premature failure and can withstand numerous loading cycles before fracture.

\section{Formulation of Problem: -}

A $18.27 \mathrm{mt} \times 28.14 \mathrm{mt}, 10$ storey regular structure is considered for the study. Modeling, analysis, estimation and design of the structure is done separately on Etabs software. The three models are design in this paper first Normal structure, Second Floating column structure with R.C.C beam girder, Third Floating column structure with composite beam girder.

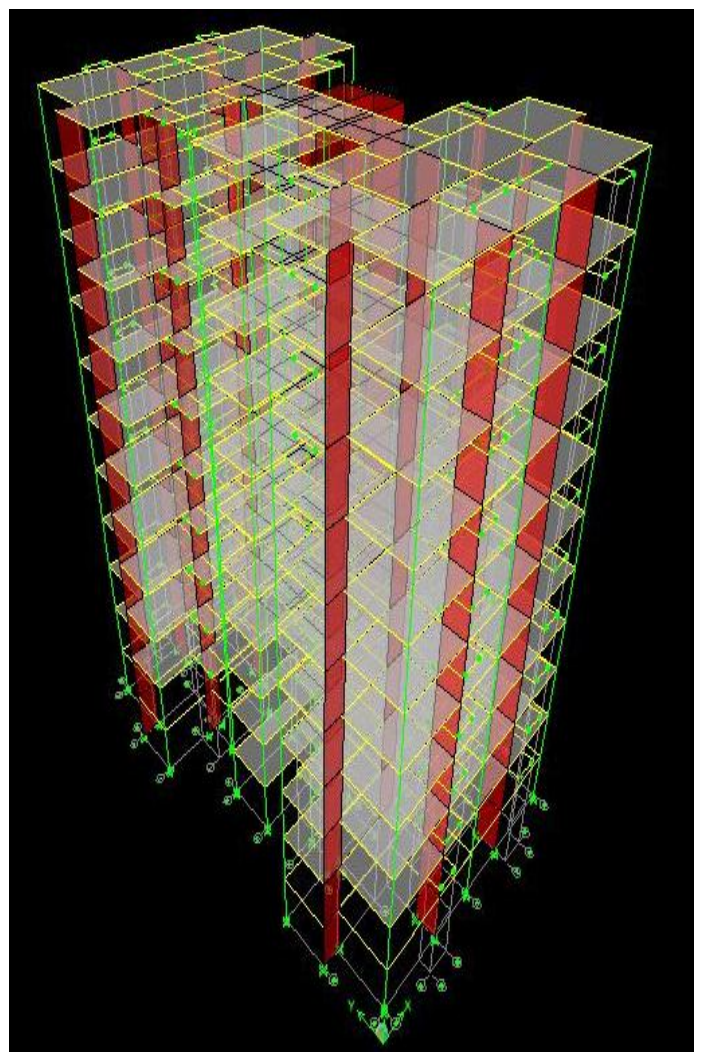

Model Considered for Analysis. (Fig. 1)

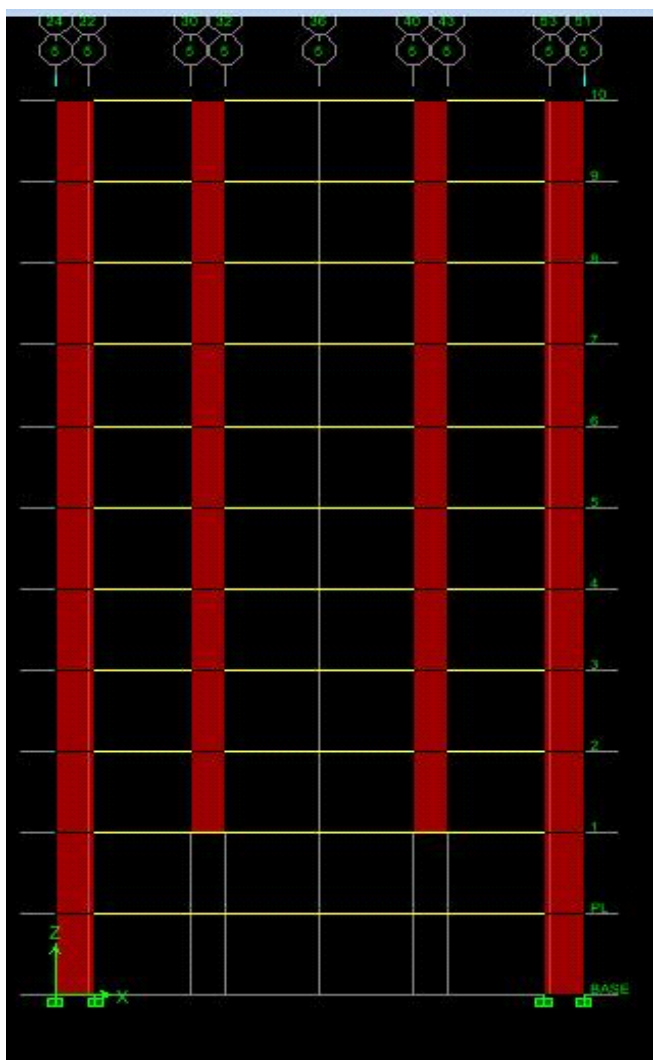

Floating column Structure with composite beam girder (Model 1) (Fig. 2) 


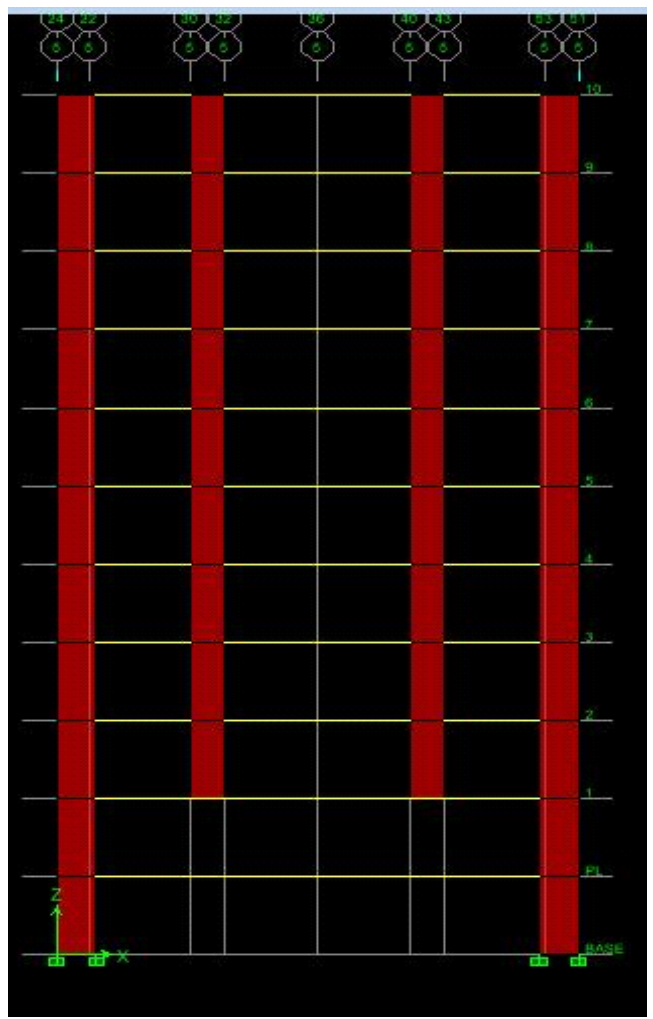

Floating column structure with R.C.C beam girder (Model 2) (Fig. 3)

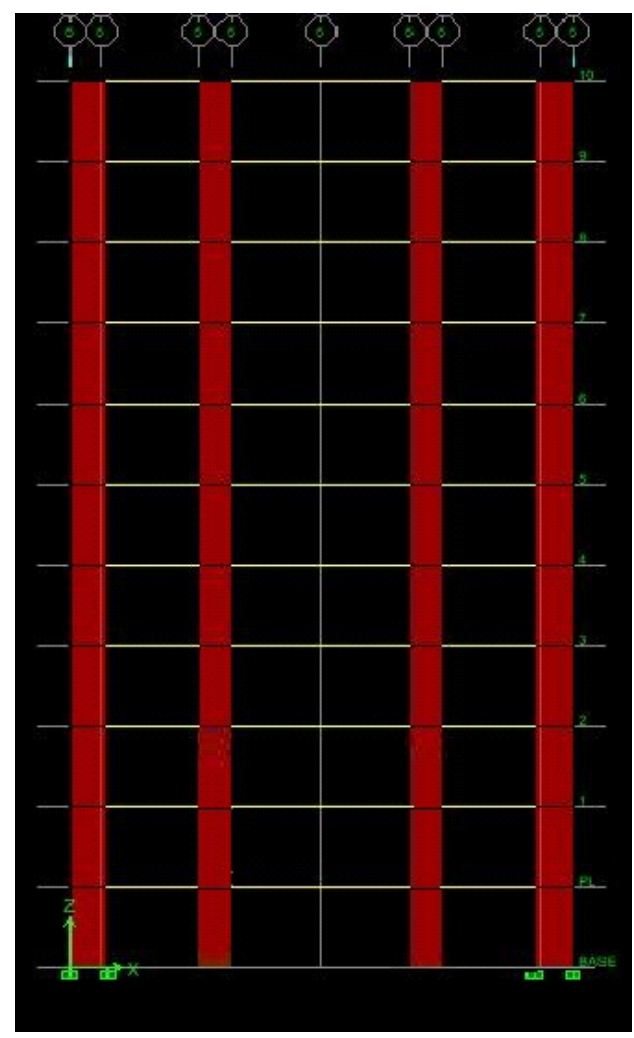

R.C.C Framed Structure (Model 3)

(Fig.4)

\section{Result and Discussion: -}

Analysis of models carried out with the horizontal component of earthquake load as per equivalent static load method and response spectrum method of IS 1893:2002(part-1). The results are presented with respect to parameters considered in present study such as base shear, displacement. Response Structure analysis was performed on Normal structure, Floating column structure with R.C.C beam girder, Floating column structure with composite beam girder using Etabs. The storey shear forces, storey drift and displacement were calculated for each floor and graph was plotted for each structure.

Table 1:- (Max Storey Shear)

\begin{tabular}{|c|c|c|c|c|}
\hline \multicolumn{5}{|c|}{ Max Storey Shear } \\
\hline $\begin{array}{c}\text { Model } \\
\text { No }\end{array}$ & \multicolumn{2}{|c|}{ RSA } & \multicolumn{2}{c|}{ EQS } \\
\cline { 2 - 5 } & $\mathrm{X}$ & $\mathrm{Y}$ & $\mathrm{X}$ & $\mathrm{Y}$ \\
\hline 1 & 1299.11 & 1111.53 & 1298.63 & 1108.4 \\
\hline 2 & 1048.55 & 817.4 & 1372.33 & 1091.59 \\
\hline 3 & 1053.07 & 829.31 & 1307.01 & 1112.9 \\
\hline
\end{tabular}

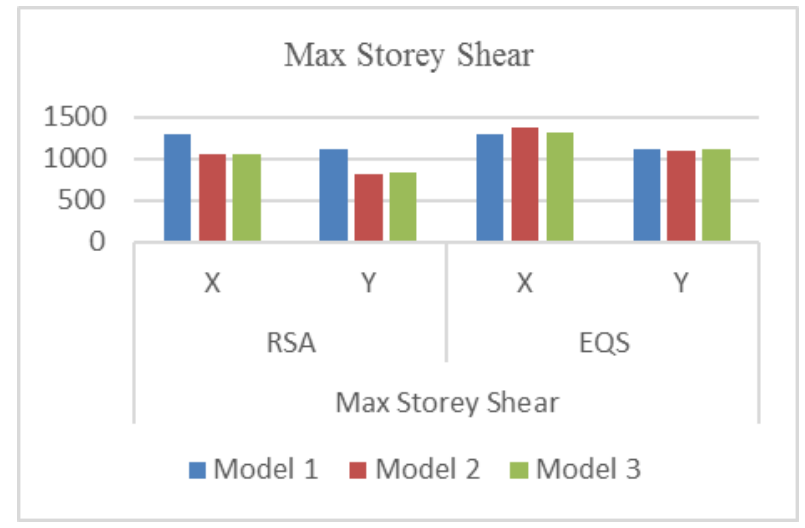


Table 2:- (Max Storey Drift)

\begin{tabular}{|c|c|c|c|c|}
\hline \multicolumn{5}{|c|}{ Max Storey Drift } \\
\hline \multirow{2}{*}{$\begin{array}{c}\text { Model } \\
\text { No }\end{array}$} & \multicolumn{2}{|c|}{ RSA } & \multicolumn{2}{c|}{ EQS } \\
\cline { 2 - 5 } & $\mathrm{X}$ & $\mathrm{Y}$ & $\mathrm{X}$ & $\mathrm{Y}$ \\
\hline & & & & \\
1 & 0.000588 & 0.000711 & 0.000551 & 0.000635 \\
\hline & & & & \\
\hline 2 & 0.000501 & 0.000507 & 0.000611 & 0.000619 \\
\hline 3 & 0.000497 & 0.000484 & 0.000581 & 0.000601 \\
\hline
\end{tabular}

Table 3: - Max Displacement

\begin{tabular}{|c|c|c|c|c|}
\hline \multicolumn{5}{|c|}{ Max Displacement } \\
\hline Model No & \multicolumn{2}{|c|}{ RSA } & \multicolumn{2}{c|}{ EQS } \\
\cline { 2 - 5 } & $\mathrm{X}$ & $\mathrm{Y}$ & $\mathrm{X}$ & $\mathrm{Y}$ \\
\hline 1 & 0.0147 & 0.0176 & 0.0142 & 0.0167 \\
\hline 2 & 0.0089 & 0.0091 & 0.014 & 0.0149 \\
\hline 3 & 0.0089 & 0.0087 & 0.0133 & 0.0144 \\
\hline
\end{tabular}

Fig. 5: - Shows Max Storey Shear

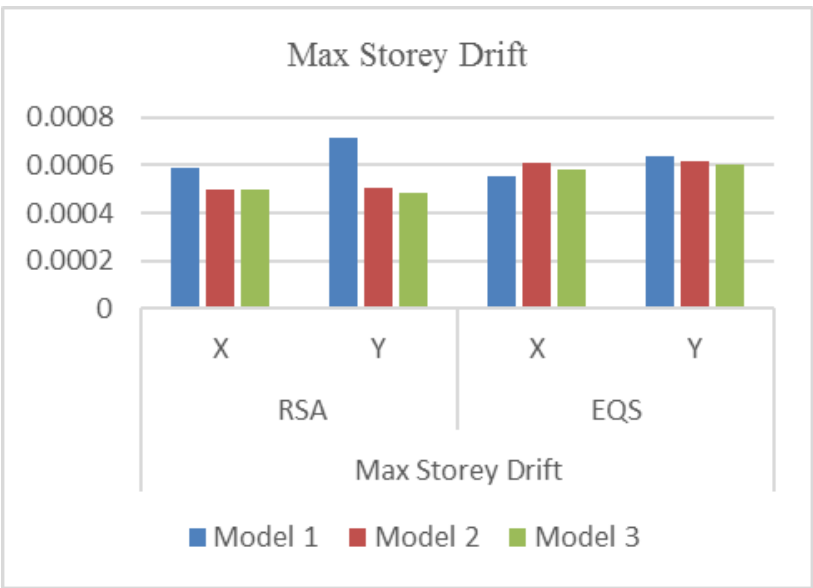

Fig. 6: - Shows Max Storey Drift.

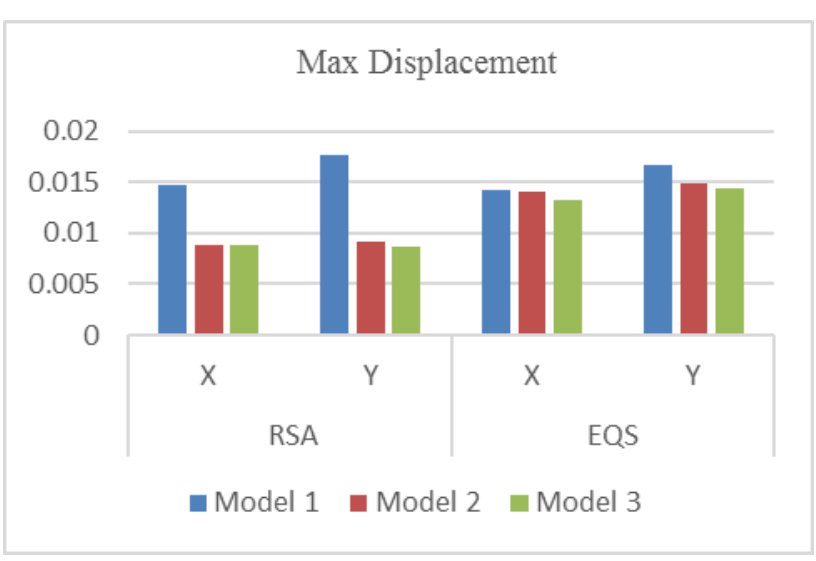

Fig 7: - Max Displacement

For Max Storey Shear - Considering the Equivalent Static method, the maximum storey shear is more than Response Spectrum method. It is found that the storey shear is maximum in Equivalent Static method in X direction for model 2 which is floating column building with R.C.C beam girder

For Max Storey Drift - Considering the Response spectrum method, the maximum storey drift is more Equivalent Static method. It is found that the storey shear is maximum in Response Spectrum method in Y direction for model 1 which is floating column building with composite beam girder.

For Max Displacement - The displacement is max in model 1 in Y direction, so the model 1 is flexible than another model. 
Table 4: -Comparison of Floating Column Structure with Composite beam girder and Normal Structure and Normal Floating Column Building.

\begin{tabular}{|c|c|c|c|}
\hline Factor & $\begin{array}{c}\text { Composite Beam Girder } \\
\text { Floating Column Building } \\
\text { (Model 1) }\end{array}$ & $\begin{array}{c}\text { R.C.C Building } \\
\text { (Model 2) }\end{array}$ & $\begin{array}{c}\text { Normal Floating Column } \\
\text { Building } \\
\text { (Model 3) }\end{array}$ \\
\hline Time Period & $1.501 \mathrm{sec}$ & $1.503 \mathrm{sec}$ & $1.50 \mathrm{sec}$ \\
\hline $\begin{array}{c}\text { Max Nodal } \\
\text { Displacement }\end{array}$ & $-26.9(1.5 \mathrm{DL}+1.5 \mathrm{EQX})$ & -26.5 & -26.9 \\
\hline $\begin{array}{c}\text { Max Support } \\
\text { Reaction }\end{array}$ & $\mathrm{P}=3293.59 \mathrm{Kn}$ & $\mathrm{P}=3020.36 \mathrm{Kn}$ & $(1.5 \mathrm{DL}+1.5 \mathrm{EQX})$ \\
\hline $\begin{array}{c}\text { Actual weight of } \\
\text { column and beam }\end{array}$ & $\mathrm{Mx}=138.39 \mathrm{Kn}-\mathrm{M}$ & $\mathrm{Mx}=128.39 \mathrm{Kn}-\mathrm{M}$ & $\mathrm{Mx}=138.39 \mathrm{Kn}-\mathrm{M}$ \\
\hline
\end{tabular}

From above table Floating Column Structure with Composite beam girder compare with and without Floating column structure, the natural time period is same because the time period is depending on the height of building and base dimension of building at plinth level. Also other factors like Max Nodal Displacement, Max Support Reaction, Actual weight of column and beam are same in second and third model because there is no change in material properties, and dimension of structural element. The Max Nodal Displacement, Max Support Reaction, Actual weight of column and beam are quite different from second and third model. Actual weight of column and beam of First model is more than other two model.

\section{Conclusion: -}

1. The plan configurations of structure have significant impact on the seismic response of structure in terms of displacement, story drift, story shear

2. As per Response Spectrum Analysis, the storey shear force was found to be maximum for the first storey and it decreased to a minimum in the top storey in all cases.

3. Maximum displacement was observed in the Floating column building with composite beam girder. It indicates that building shows flexibility with maximum displacement and storey drift.

4. According to results of Response Spectrum Analysis, it was found that Floating Column Structure with composite beam girder experience larger base shear than Normal Structure and Floating column with R.C.C beam girder.

5. It is observed that the storey drift for all the stories are found to be within the permissible limits

\section{References: -}

1. Arlekar, Jain and Murty (1997). "Seismic response of RC frame building with soft first story." "Proceeding of the CBRI Golden Jubilee Conference on Natural Hazards in Urban", 1997.

2. Balsamoa, Colombo and Manfredi (2005) Seismic behavior of a full-scale RC frame repaired using CFRP laminates". "Engineering Structure" 27 (2005) 223-233.

3. Hardik Bhensdadia, Siddharth Shah (2015) "Pushover analysis of frame RC frame structure with floating column and soft story in different earthquake zone". "International Journal of Research in engineering and Technology" Vol 4. Issue 4, April 2015

4. Mounir Bouassia, Belgacem Jellali and Porbaha (2009) "Limit analysis of rigid foundation on floating column". "Article in International Journal of Geo-mechanics". Vol.9, No. 3, June 1, 2009.

5. Pratyush Malaviya (May 2014) "Comparative study of effect of floating column on the cost analysis of a structure design on Staad pro v8i" Internationals Journal of Science and Engineering Research May 2014

6. Sreekanth Nanabala, Pradeep Kumar and Arunakadhi (2014). "Seismic analysis of a normal building and floating column building", "International Journal of Engineering Research and Technology". Vol.3 Issue 9, Sept 2014.

7. Sukumar Behera (2012), "Seismic analyses of multistory building with floating column", "National Institute of Technology" 